\title{
ANALYSIS OF LEUKOTOXIN GENE TYPES OF ACTINOBACILLUS ACTINOMYCETEMCOMITANS IN BRAZILIANS WITH AGGRESSIVE PERIODONTITIS
}

\author{
Wilson Rosalem Junior ${ }^{1,2}$; Rodrigo Carvalho de Souza ${ }^{3,4}$; Arnaldo Feitosa Braga de Andrade ${ }^{1}$; \\ Ana Paula Vieira Colombo ${ }^{5 *}$
}

${ }^{1}$ Departamento de Microbiologia, Universidade Estadual do Rio de Janeiro, Rio de Janeiro, RJ, Brasil; ${ }^{2}$ Disciplina de Periodontologia, Faculdade de Odontologia da Universidade Estácio de Sá, Rio de Janeiro, RJ, Brasil; ${ }^{3}$ Departamento de Periodontologia, Faculdade de Odontologia, Universidade Federal do Rio de Janeiro, Rio de Janeiro, RJ, Brasil; ${ }^{4}$ Disciplina de Periodontologia, Faculdade de Odontologia da Universidade Salgado de Oliveira, Niterói, RJ, Brasil; ${ }^{5}$ Departamento de Microbiologia Médica, Instituto de Microbiologia, Universidade Federal do Rio de Janeiro, Rio de Janeiro, Brasil

Submitted: August 17, 2005; Approved: February 26, 2006

\begin{abstract}
Actinobacillus actinomycetemcomitans (Aa) is considered a major etiologic agent of aggressive periodontitis but this species has also been associated with other forms of periodontal disease. Further, highly leukotoxic strains are related to severity of disease. The purpose of this study was to determine the prevalence of $A a$ and the occurrence of the leukotoxin gene 530-bp deletion in patients with generalized aggressive periodontitis (GAP) from a Brazilian population. Thirty periodontally healthy and 29 GAP subjects participated in the study. Full-mouth periodontal examination including probing pocket depth (PPD), clinical attachment level (CAL), supragingival biofilm (SB) and bleeding on probing (BOP) was carried out at 6 sites/tooth for all subjects. Whole saliva samples were collected for bacterial DNA isolation. The detection of $A a$ and the presence of the 530-bp genetic deletion were determined directly in the samples by polimerase chain reaction. Differences on clinical and microbiological parameters between the two groups were sought using the MannWhitney, Fisher's exact and Chi-square tests. Associations between clinical and microbiological parameters were tested using the Pearson correlation coefficient. Aa was detected significantly more often in GAP patients $(96.6 \%)$ than healthy subjects $(76.7 \%)\left(\chi^{2}=4.9 ; p<0.05\right)$. The genetic deletion was observed in 16 of the $28(57.1 \%)$ GAP patients who were positive for $A a$. However, none of the samples from individuals with periodontal health presented this deletion $\left(\chi^{2}=19.15 ; \mathrm{p}<0.001\right)$. Strong correlations between the presence of the deletion and $\mathrm{PPD}(\mathrm{r}=0.312, \mathrm{p}<0.05), \mathrm{CAL}(\mathrm{r}=0.409, \mathrm{p}<0.01), \mathrm{SB}(\mathrm{r}=0.278, \mathrm{p}<0.05)$ and $\mathrm{BOP}(\mathrm{r}=0.406, \mathrm{p}<0.01)$ were found. A high frequency of $A a$ was observed in Brazilians with GAP and periodontal health. However, the highly leukotoxic genotype was observed only in subjects with generalized aggressive disease.
\end{abstract}

Key words: generalized aggressive periodontitis, PCR, Actinobacillus actinomycetemcomitans, saliva, leukotoxin

\section{INTRODUCTION}

Actinobacillus actinomycetemcomitans is a Gram-negative, small and capnophilic anaerobe rod with a primary habitat in the dental biofilm of humans. Several lines of evidence suggest that this species play a significant role in the etiopathogenesis of aggressive, as well as severe forms of chronic periodontitis $(38,39,53)$. However, this organism may also be detected in a significant percentage (17 to $41 \%$ ) of periodontally healthy individuals, and may constitute a persistent member of the normal oral microbiota $(11,16,34,52)$.

*Corresponding Author. Mailing address: R. Gal. Dionísio, 60, apt. 804, Humaitá. 22271-050, Rio de Janeiro, RJ, Brasil. E-mail: anapaulacolombo@ yahoo.com orapcolombo@micro.ufrj.br 
This species has a great intra - specific diversity determined by different serotypes and genotypes $(17,23,25,26)$. For instance, serotypes $\mathrm{a}$ and $\mathrm{b}$ are the most associated with aggressive periodontal diseases (54). In contrast, serotype $\mathrm{c}$ was the most frequently detected type in individuals with chronic periodontitis from the Chinese and Brazilian populations $(31,43)$. Therefore, different strain types may be related to various periodontal clinical status in individuals from populations with different ethnic backgrounds.

An important virulence factor of A. actinomycetemcomitans is a potent leukotoxin that specially kills human leukocytes (6). The toxin is encoded by a gene operon consisting of four genes designated $l t x C$, ltxA, ltxB and $l t x D$. The ltxA gene is essential for cytolytic activity since deletion of a repeat domain common to all RTX toxin proteins in this region renders the leukotoxin inactive $(19,28)$. Strains that demonstrate a 530-bp deletion in the promoter region of the leukotoxin gene operon exhibit enhanced leukotoxin production $(9,25)$. Studies have shown an association between highly leukotoxic strains of A. actinomycetemcomitans and sites with destructive periodontal disease, particularly aggressive periodontal diseases (12,24-26,43,55). Zambon et al., 1996 (55) detected the 530-bp deletion in A. actinomycetemcomitans isolates from 12 of 21 aggressive periodontitis patients but not in isolates from 11 periodontally healthy and 5 chronic periodontitis subjects. In addition to periodontal clinical status, the frequency of $A$. actinomycetemcomitans strains presenting the 530-bp deletion seems to vary greatly in individuals from different populations (22-24,26,55). Haubek et al., 1997 (25) found the genetic deletion in $44 \%$ of A. actinomycetemcomitans strains from individuals of north and west Africa. In contrast, none of the isolates from subjects in north Europe presented the deletion (Haubek et al., 1995) (23).

It has recently been demonstrated that this putative periodontal pathogen is commonly recovered from saliva $(4,50)$. Although whole saliva has no distinctive microbiota of its own (7), it harbors as much as $10^{8}$ bacteria $/ \mathrm{mL}$, and is a reservoir of microorganisms regularly derived from supra and subgingival dental biofilm, dorsum of the tongue, and other oral mucosal surfaces (48). Some studies have suggested that the use of whole saliva may be superior to pooled periodontal pocket samples for the detection of certain periodontal pathogens, particularly when employing a highly sensitive and specific method such as the polymerase chain reaction (PCR) technique $(3,32,35,36)$. Moreover, this is a rapid, non invasive, inexpensive and easy method of sampling $(4,47)$.

Given that different ethnic populations with clinically distinct periodontal conditions seem to show varying frequency of $A$. actinomycetemcomitans strain types, the purpose of this study was to determine the prevalence of A. actinomycetemcomitans and the occurrence of the leukotoxin gene 530-bp deletion in patients with generalized aggressive periodontitis from a Brazilian population.

\section{MATERIALS AND METHODS}

\section{Subject population}

Twenty-nine patients with generalized aggressive periodontitis (GAP) were recruited from the pool of patients at the Dental School of the Federal University of Rio de Janeiro, Brazil. In addition, thirty age-matched periodontally healthy control subjects who visited the Dental School for regular checkups volunteered for the study. In order to participate, informed consent was obtained from all individuals. The protocol for the study was approved by the review Committee for Human Subjects of the Clementino Fraga Filho University Hospital. Healthy controls were over 21 years of age and showed no sites with probing pocket depth (PPD) $>3 \mathrm{~mm}$, clinical attachment level $(\mathrm{CAL})>4 \mathrm{~mm}$, and bleeding on probing $(\mathrm{BOP})>5 \%$. The GAP group was defined according to clinical and radiographic classification criteria of the International Classification Workshop of 1999; i.e. < 30 years of age, pronounced episodic destruction of attachment and alveolar bone, and generalized interproximal attachment loss affecting at least three permanent teeth other than first molars and incisors (2,29). Regarding race, the patients were defined (by self-reporting) as White, AfricanBrazilian and others. Exclusion criteria included: $<15$ teeth, pregnancy, use of antibiotics within 6 months prior to the entry into the study, smoking, diabetes and other systemic conditions that could affect the periodontal status.

\section{Clinical measurements}

Clinical measurements were performed at 6 sites per tooth at all teeth excluding third molars. They included PPD and CAL $(\mathrm{mm})$ measured with a conventional North Carolina periodontal probe (HU-Friedy, Chicago, IL, USA), and presence or absence of supragingival biobilm accumulation (SB) and bleeding on probing (BOP). All clinical measurements were performed by one calibrated examiner.

\section{A. actinomycetemcomitans detection by PCR}

DNA isolation from mouthwash samples was carried out as described by Laine et al. (27). Briefly, the patients were not allowed to clean their teeth or to eat 30 minutes before sampling. They rinsed out their mouths twice with $10 \mathrm{~mL}$ of $0.9 \%$ sterile saline for 60 seconds. Mouthwash samples were centrifuged at $300 \mathrm{xg}$ for 10 minutes. The pellet was washed twice in $0.9 \%$ saline, re-suspended in $100 \mu \mathrm{L}$ of $50 \mathrm{mM} \mathrm{NaOH}$, and boiled for 10 minutes. Samples were neutralized with $14 \mu \mathrm{L}$ of $1 \mathrm{M}$ Tris $(\mathrm{pH}$ 7.5) and centrifuged at $14.000 \mathrm{x}$ g for 3 minutes. Supernatants were collected and stored at $4^{\circ} \mathrm{C}$ until PCR amplification was performed.

Synthetic oligonucleotides (Invitrogen Brazil, São Paulo, SP) targeting the leukotoxin gene ltxA of the ltx operon were used to detect $A$. actinomycetemcomitans by PCR. The strain A. actinomycetemcomitans ATCC 29523 was used as positive 
control. The primers for $l t x A$ used in this study were designed by Tonjum and Haas, 1993 (46). The sequences of the forward and reverse primers were TT-15(5'-TCG CGA ATC AGC TCG CCG -3') and TT-16(5'-GCT TTG CAA GCT CCT CAC C-3'), respectively. Samples were amplified in a $50 \mu \mathrm{L}$ reaction mixture, containing $10 \mathrm{ng}$ of template DNA, $10 \mathrm{mM}$ Tris-HCl, 50 $\mathrm{mM} \mathrm{KCl}, 2 \mathrm{mM} \mathrm{MgCl}_{2}$ (Biotools do Brasil Ltda., Rio de Janeiro, Brazil), $200 \mu \mathrm{M}$ of each deoxynucleosidetriphosphate (Biotools), $0.5 \mu \mathrm{M}$ solution of each primer, and $0.5 \mathrm{U}$ of Taq polymerase (Biotools). PCR program was performed in a thermocycler (Primus 25/96, MWG - Biotech, Ebersberg, Germany), with a few modifications from the program described by Tan et al., 2001 (41). It included an initial denaturation cycle of $94^{\circ} \mathrm{C}$ for 3 min, followed by 35 cycles of denaturation at $94^{\circ} \mathrm{C}$ for $1 \mathrm{~min}$, annealing at $60^{\circ} \mathrm{C}$ for $1 \mathrm{~min}$ and extension at $72^{\circ} \mathrm{C}$ for $1 \mathrm{~min}$. The final extension was carried out at $72^{\circ} \mathrm{C}$ for $10 \mathrm{~min}$. The PCR products were analyzed by electrophoresis on a $1.5 \%$ agarose gel. The gel was treated with ethidium bromide $(0.5 \mu \mathrm{g} / \mathrm{mL})$ and visualized on an ultraviolet transilluminator. The presence of $A$. actinomycetemcomitans was determined by a distinct band of $285 \mathrm{bp}$ in size. A pair of ubiquitous bacterial primers (5'-AGA GTT TGA TCC TGG CTC AG-3' and 5'-ACG GCT ACC TTG TTA CGA CTT- 3') (Biotools), designed by Willis et al., 1999 (51), which match almost all bacterial 16s RNA genes at the same position but not 18s RNA genes from eukaryotic cells, was used to indicate the presence of bacterial DNA in the clinical samples, particularly the ones that were $A$. actinomycetemcomitans-negative. For the reaction using universal $16 \mathrm{~S}$ rDNA primers, $\mathrm{PCR}$ amplification was performed in a thermocycler (Primus 25/96, MWG - Biotech), and included a $25 \mu \mathrm{L}$ reaction mixture containing $0.2 \mu \mathrm{M}$ of forward and reverse universal primers, $2.5 \mu \mathrm{L}$ of 10X PCR buffer (Biotools), $2 \mathrm{mM}$ $\mathrm{MgCl}_{2}, 1.25 \mathrm{U}$ of Tth DNA Polymerase (Biotools), $200 \mu \mathrm{M}$ of each deoxynucleosidetriphosphate (Biotools). The PCR temperature profile included an initial denaturation step at $97^{\circ} \mathrm{C}$ for $1 \mathrm{~min}$, followed by 30 cycles of a denaturation step at $97^{\circ} \mathrm{C}$ for $45 \mathrm{~s}$, a primer annealing step at $55^{\circ} \mathrm{C}$ for $45 \mathrm{~s}$, an extension step at $72^{\circ} \mathrm{C}$ for $1 \mathrm{~min}$ and a final step of $72^{\circ} \mathrm{C}$ for $4 \mathrm{~min}$. The presence of bacterial DNA was determined by an amplicon of $1505 \mathrm{bp}$ in size visualized on a $1.5 \%$ agarose gel.

\section{Determination of the leukotoxin gene promoter (ltx) type}

In the A. actinomycetemcomitans-positive samples, PCR was carried out for determining the ltx promoter type. The set of primers A ( $5^{\prime}$ - TCCATATTAAATCTCCTTGT-3') and B (5' AACCTGATAACAGTATT-3') (Invitrogen Brazil) designed by Zambon et al., 1996 (55) were selected. Briefly, $100 \mathrm{ng}$ of genomic DNA was mixed with $100 \mathrm{ng}$ of each oligonucleotide primer, in the appropriate buffer. Samples were amplified in a $50 \mu \mathrm{L}$ reaction mixture, containing $15 \mathrm{ng}$ of template DNA, $10 \mathrm{mM}$ Tris- $\mathrm{HCl}, 50 \mathrm{mM} \mathrm{KCl}, 2 \mathrm{mM} \mathrm{MgCl}{ }_{2}$ (Biotools), $200 \mu \mathrm{M}$ of each deoxynucleotide triphosphate (Biotools), 50 pmol of each primer, and $1.5 \mathrm{U}$ of Taq polymerase (Biotools). An initial denaturation cycle $\left(95^{\circ} \mathrm{C}\right.$ for $\left.5 \mathrm{~min}\right)$ was followed by 25 cycles of $30 \mathrm{~s}$ at $95^{\circ} \mathrm{C}$, $30 \mathrm{~s}$ at $55^{\circ} \mathrm{C}$, and $30 \mathrm{~s}$ at $72^{\circ} \mathrm{C}$. This was followed by a final cycle of $30 \mathrm{~s}$ at $95^{\circ} \mathrm{C}, 30 \mathrm{~s}$ at $55^{\circ} \mathrm{C}$, and $9 \mathrm{~min}$ at $72^{\circ} \mathrm{C}$. These primers amplify a 492 bp product from highly toxic strains and a $1022 \mathrm{bp}$ product from non leukotoxic strains. The amplicons were analyzed by electrophoresis on a $1.5 \%$ agarose gel. The gel was stained with ethidium bromide $(0.5 \mu \mathrm{g} / \mathrm{mL})$ and visualized on an UV transilluminator.

\section{Statistical analysis}

Full mouth clinical measurements were computed for each subject and then averaged across subjects within the groups. The frequency of detection of A. actinomycetemcomitans and the 530-bp deletion was determined for each group. Differences on clinical and microbiological parameters between the two groups were sought using the Mann-Whitney, Chi-square and Fisher's exact tests. Analysis of covariance (General Linear Model - GLM) was performed to investigate the possible effects of gender and race (covariates) in the differences of clinical parameters between groups. Associations between clinical and microbiological parameters were tested using the Pearson correlation coefficient. Any difference of $p<0.05$ was considered statistically significant.

\section{RESULTS}

The periodontal clinical parameters of the two subject groups are shown in Table 1. No significant differences between the groups were observed regarding age $(p=0.698)$ and race $(p=$ 0.080 ); however a significantly greater percentage of males was observed in the healthy group $(p=0.006)$. Subjects with GAP presented significantly higher mean PPD $(p<0.001)$ and CAL $(p<0.001)$, as well as mean number of missing teeth $(p<0.01), \%$ of sites with SB $(p<0.001)$, BOP $(p<0.001)$, deep pockets and severe attachment loss $(p<0.001)$ than periodontally healthy individuals. Due to significant differences in gender between the groups, and the association of race with aggressive periodontal diseases, these variables were used as covariates in the analysis of covariance (GLM test). Even after controlling for these factors, the differences between the groups were statistically significant for all clinical measurements $(p<0.001)$.

The microbiological data is depicted in Table 2. A. actinomycetemcomitans was detected in $86.4 \%$ of the subjects from this sample population. A significant higher prevalence of this species was observed in the GAP patients (96.6\%) compared to periodontally healthy controls $(76.7 \%)\left(\chi^{2}=4.97 ; \mathrm{p}=0.026\right)$. Out of the 51 subjects who were positive for $A$. actinomycetemcomitans, $54.9 \%$ presented the 530-bp leukotoxin deletion. Further, the leukotoxin deletion was observed in 16 of the $28(57.1 \%)$ GAP patients. However, none of the $23 \mathrm{~A}$. actinomycetemcomitans-positive individuals in the periodontal 
Table 1. Full mouth clinical parameters (mean \pm SEM) of periodontally healthy and generalized aggressive periodontitis (GAP) subjects selected from a Brazilian population.

\begin{tabular}{|c|c|c|c|}
\hline & $\begin{array}{c}\text { Periodontally } \\
\text { Healthy } \\
(\mathrm{N}=30)\end{array}$ & $\begin{array}{l}\text { GAP } \\
(\mathrm{N}=29)\end{array}$ & $p$ \\
\hline Age * & $30.2 \pm 6.9^{\text {II }}$ & $26.9 \pm 8.4^{\pi}$ & $=0.698$ \\
\hline $\begin{array}{l}\text { Gender }(\%)^{\dagger} \\
\text { males/females }\end{array}$ & $63 / 37$ & $28 / 72$ & $=0.006$ \\
\hline $\operatorname{Race}(\%) *$ & & & \\
\hline African Brazilians & 7 & 24 & \\
\hline Whites & 93 & 76 & $=0.080$ \\
\hline Others & 0 & 0 & \\
\hline $\begin{array}{l}\text { Number of missing teeth*\| } \\
\text { Mean Probing Pocket }\end{array}$ & $1.5 \pm 2.1^{\mathbb{I I}}$ & $3.3 \pm 2.8^{\pi}$ & $<0.01$ \\
\hline $\begin{array}{l}\text { Depth }(\mathrm{mm}) * \| \\
\text { Mean Clinical }\end{array}$ & $1.8 \pm 0.05$ & $3.7 \pm 0.2$ & $<0.001$ \\
\hline $\begin{array}{l}\text { Attachment Level }(\mathrm{mm}) * \| \\
\% \text { sites with: }\end{array}$ & $1.9 \pm 0.04$ & $4.1 \pm 0.2$ & $<0.001$ \\
\hline Bleeding on probing*\| & $9 \pm 1.5$ & $56.6 \pm 5.3$ & $<0.001$ \\
\hline Supragingival biofilm*\| & $23.9 \pm 2.5$ & $47.5 \pm 4.6$ & $<0.001$ \\
\hline Pocket depth $<4 \mathrm{~mm} * \|$ & $98.5 \pm 0.3$ & $55.1 \pm 5.3$ & $<0.001$ \\
\hline Pocket depth 4-6 mm*\| & $1.5 \pm 0.2$ & $26.7 \pm 2.6$ & $<0.001$ \\
\hline Pocket depth $>6$ mm*\| & 0 & $18.2 \pm 3.5$ & $<0.001$ \\
\hline Attachment level $<4$ mm*\| & $98.1 \pm 0.5$ & $43.9 \pm 5$ & $<0.001$ \\
\hline Attachment level 4-6 mm*\| & $1.9 \pm 0.3$ & $33.1 \pm 2.9$ & $<0.001$ \\
\hline Attachment level $>6$ mm*\| & 0 & $23 \pm 3.8$ & $<0.001$ \\
\hline
\end{tabular}

* Refers to Mann-Whitney test; ${ }^{\dagger}$ Chi-square test; ${ }^{\ddagger}$ Fisher’s exact test; ${ }^{\|}$Analysis of covariance (GLM test) using gender and race as covariates; ${ }^{\text {II }}$ Standard deviation (SD).

health group presented this deletion $\left(\chi^{2}=19.2 ; p<0.001\right)$. Bivariate correlation analysis demonstrated a modest positive association between the presence of $A$. actinomycetemcomitans and CAL $(r=0.287, p=0.028)$ (Table 3$)$. However, stronger correlations between the presence of the genetic deletion and periodontal clinical parameters such as $\operatorname{PPD}(\mathrm{r}=0.312, \mathrm{p}=0.016)$,
$\mathrm{CAL}(\mathrm{r}=0.409, \mathrm{p}=0.001), \mathrm{SB}(\mathrm{r}=0.278, \mathrm{p}=0.033)$ and

$\mathrm{BOP}(\mathrm{r}=0.406, \mathrm{p}=0.009)$ were found (Table 3$)$.

\section{DISCUSSION}

According to the criteria for defining pathogens of destructive periodontal diseases, one of the strongest associations between a periodontal pathogen and aggressive forms of periodontitis is provided by A. actinomycetemcomitans (21). Despite of that, this species has also been frequently detected in sites and/or subjects with periodontal health and other forms of periodontitis (39). Thus, only the presence of a pathogen does not seem to be sufficient to cause disease. In fact, other factors necessary for disease progression should be considered such as the levels of the pathogen, the predominance of a virulent clonal type, the levels of beneficial species, as well as environmental and genetic features associated with a susceptible host (40). In the present study, we evaluated the prevalence of $A$. actinomycetemcomitans and the distribution of the genetic deletion in the leukotoxin promoter region associated with a more virulent clonal type in individuals with aggressive periodontitis from a subset of the Brazilian population. Among the 29 individuals with aggressive periodontitis examined, 28 were colonized by A. actinomycetemcomitans. Similar results were reported by studies in the Brazilian population, particularly in patients with aggressive periodontitis $(13,14,43-45)$, as well as in individuals from other geographic locations $(18,37,39,52,53)$. These data strengthen the etiologic role of $A$. actinomycetemcomitans in aggressive forms of periodontitis. Nevertheless, a very high frequency of this species was also observed in individuals with periodontal health (76.7\%). Other studies have demonstrated a prevalence varying from $25 \%$ to over $60 \%$ of this species in individuals or sites with no periodontal destruction $(1,5,11,18,20,30,44)$. Differences in virulence may be one explanation for the high detection of $A$.

Table 2. Prevalence of A. actinomycetemcomitans and the 530 bp leukotoxin deletion in periodontally healthy and generalized aggressive periodontitis (GAP) subjects selected from a Brazilian population.

\begin{tabular}{lccc}
\hline & $\begin{array}{c}\text { Periodontally Healthy } \\
(\mathrm{N}=30)\end{array}$ & GAP & Total \\
& $(\mathrm{N}=29)$ & $(\mathrm{N}=59)$ \\
\cline { 2 - 4 } A. actinomycetemcomitans $^{*}$ & $23 / 30(76.7 \%)$ & $28 / 29(96.6 \%)$ & $51 / 59(86.4 \%)$ \\
530 bp leukotoxin deletion $^{\dagger}$ & $0 / 23(0)$ & $16 / 28(57.1 \%)$ & $28 / 51(54.9 \%)$ \\
\hline
\end{tabular}

* Significant difference was observed between the groups $\left(\chi^{2}=4.97 ; \mathrm{p}=0.026\right)$;

${ }^{\dagger}$ Significant difference was observed between the groups $\left(\chi^{2}=19.15 ; \mathrm{p}<0.001\right)$. 
Table 3. Correlations between the prevalence of A. actinomycetemcomitans and the 530-bp leukotoxin deletion and clinical periodontal parameters in subjects selected from a Brazilian population.

\begin{tabular}{lcc}
\hline & A. actinomycetemcomitans & $\begin{array}{c}530-\text { bp leukotoxin } \\
\text { deletion }\end{array}$ \\
\cline { 2 - 3 } $\begin{array}{l}\text { Probing Pocket } \\
\text { Depth (mm) }\end{array}$ & $* 0.249(0.057)^{\mathrm{NS}}$ & $* 0.312(0.016) \dagger$ \\
$\begin{array}{l}\text { Clinical Attachment } \\
\text { Level (mm) }\end{array}$ & $* 0.287(0.028) \dagger$ & $* 0.409(0.001) \dagger$ \\
$\begin{array}{l}\% \text { sites with: } \\
\text { Bleeding on probing }\end{array}$ & $* 0.175(0.184)^{\mathrm{NS}}$ & $* 0.406(0.001) \dagger$ \\
Supragingival biofilm & $* 0.190(0.149)^{\mathrm{NS}}$ & $* 0.278(0.033) \dagger$ \\
\hline
\end{tabular}

$*_{\mathrm{r}}=$ Pearson's correlation coefficient; $\mathrm{NS}=$ not significant; $\uparrow \mathrm{p}$ value.

actinomycetemcomitans in periodontally diseased subjects as well as in healthy carriers. In fact, our data showed that of the 28 A. actinomycetemcomitans-positive individuals with GAP, $57.1 \%$ presented the leukotoxin 530-bp deletion. In contrast, none of the individuals with periodontal health showed this genetic deletion. Haraszthy et al. (22) examined a very large number of isolates from patients with different forms of periodontitis and observed that the highly leukotoxic type strains were detected only in patients with aggressive disease. Likewise, a particularly strong correlation between aggressive periodontitis and the highly leukotoxic A. actinomycetemcomitans strains was reported for a group of Brazilians with various forms of periodontal disease $(13,14)$. Other authors have also demonstrated this correlation $(9,24,25,55)$. An interesting finding reported by Bueno et al. (10) was that subjects harboring the leukotoxic strain were 22.5 times more likely to convert from periodontal health to localized aggressive periodontitis than subjects who had variants containing the full- length leukotoxin promoter region. These data indicate that high levels of leukotoxin could be directly involved in the periodontal destruction. Conversely to these data, only $16 \%$ of the isolates from Brazilians with LJP presented the 530-bp deletion in the study by Tinoco et al. (43). Moreover, some investigations have reported no relationship between leukotoxic type strains and severe periodontitis in Asian subjects $(12,31,41)$. Conceivably, the occurrence of the virulent clonal type of $A$. actinomycetemcomitans may be restricted to a specific race or ethnic group, as pointed out by Haubek et al. (25). These authors found that the leukotoxic strain type and aggressive periodontitis were related mainly to individuals with a genetic background in an African population. In addition, it is possible that this species may cause two different types of aggressive periodontitis: one type, found worldwide, in which a diversity of clones may act as an opportunistic pathogen, and another type, in which the leukotoxic type of A. actinomycetemcomitans acts as an exogenous pathogen. Thus, epidemiological studies of this microorganism from periodontally healthy and diseased individuals in relevant populations are needed to answer these questions. In the current study, the subjects were classified (by self-reporting) as White, African-Brazilian and others. Data from the Census 2003 reported by the Brazilian Institute of Geography and Statistics demonstrated a prevalence of $58.1 \%$ of Whites, $10.9 \%$ African-Brazilians, $30.8 \%$ mulattos and $0.2 \%$ Indians in the urban population of the city of Rio de Janeiro (8). However, no reliable criteria to define these groups are available due to the high racial miscegenation in this population. We observed a high prevalence of Whites $(>80 \%)$ in this sample population but this classification may have been subjective. A higher proportion of AfricanBrazilians was found in the GAP group compared to healthy controls. Despite that, the clinical and microbiological findings were similar when the data was controlled for this factor (data not shown).

Regarding the methodology employed, the mouthwash samples were very efficient for detection of $A$. actinomycetemcomitans, as confirmed by other authors $(15,33,42,47)$. Actually, using of saliva instead of plaque samples may have accounted for the high prevalence of this species, including in periodontally healthy patients. For instance, in other microbiological studies by our group using plaque samples from individual subgingival sites, we observed a much lower prevalence of A. actinomycetemcomitans (40\%) in Brazilians with periodontal health (data not shown). Other aspect that should be considered is the fact that if a subject harbored the two clonal types of A. actinomycetemcomitans in different sites in the oral cavity, those strains would be probably detected in saliva but could be missed when using individual plaque samples. The primers used to detect $A$. actinomycetemcomitans were carefully selected, according Tonjum and Haas (46). These primers, based on the leukotoxin structural gene of this pathogen, were elaborated to be very specific, showing clearly a high capability to distinguish this species from the closely related Haemophilus aphrophilus as well as species harboring RTX (repeats in toxin) family-related cytotoxins.

Many times the clinician is not able of distinguishing a severe chronic periodontitis from an aggressive periodontitis based on clinical and radiographic parameters. The main relevance of this type of study is to provide an additional microbiological tool for a more precise diagnosis, since we are talking about an infectious disease, and therefore a less empiric periodontal treatment. For instance, we have found a very high prevalence of A. actinomycetemcomitans in patients with chronic periodontitis from this population. Nevertheless, no correlation between highly leukotoxic A. actinomycetemcomitans and chronic disease was observed (data not shown). One could 
then speculate that individuals with extensive periodontal destruction harboring highly leukotoxic strains are more likely to present an aggressive disease. Further, it is possible that those patients would require a more intense periodontal therapy, including mechanical procedures associated with local and/or systemic antimicrobial agents (49).

In summary, the data of the present investigation demonstrated a very high prevalence of A. actinomycetemcomitans in a subset of the Brazilian population. However, the highly leukotoxic clonal type predominated in patients with generalized aggressive periodontitis, suggesting an association between this genotype and destructive periodontal disease.

\section{ACKNOWLEDGMENTS}

This work was supported in part by Program of Research Support for Groups of Excellence (PRONEX), National Council for Scientific and Technological Development (CNPq), and Foundation for Research Financial Support in the State of Rio de Janeiro (FAPERJ), Brazil.

\section{RESUMO}

\section{Análise de genes da leucotoxina de Actinobacillus actinomycetemcomitans em brasileiros com periodontite agressiva}

Actinobacillus actinomycetemcomitans (Aa) tem sido associado com diferentes formas de doenças periodontais, mas tal espécie é considerada o principal agente etiológico da doença periodontal agressiva. Algumas cepas de $A a$ apresentam uma deleção de $530 \mathrm{pb}$ na região promotora do operon do gene da leucotoxina, produzindo assim maiores quantidades de leucotoxina. Tal fato pode ter um importante papel na patogênese das doenças periodontais. A proposta do presente estudo foi determinar a prevalência do $A a$ e a ocorrência da deleção genética da leucotoxina em pacientes com periodontite agressiva generalizada (PAG) de uma amostra da população brasileira. Trinta indivíduos com saúde periodontal e 29 pacientes com PAG participaram do estudo. Profundidade de bolsa à sondagem (PBS), nível clínico de inserção (NCI), presença de placa supragengival (PL) e sangramento à sondagem (SAS) foram avaliados em 6 sítios/dente de todos os pacientes. Amostras de saliva foram coletadas para isolamento do DNA bacteriano. A detecção do $A a$ e a ocorrência da deleção genética foram realizadas através da técnica de PCR diretamente nas amostras. Diferenças nos parâmetros clínicos e microbiológicos entre os grupos foram avaliadas através dos testes de MannWhitney, Fisher e Qui-quadrado. Associações entre os parâmetros clínicos e microbiológicos foram testadas através do teste de Pearson. Aa foi detectado com maior frequência em pacientes com PAG $(96,6 \%)$ do que pacientes saudáveis $(76,7 \%)$ $\left(\chi^{2}=4,9 ; p<0,05\right)$. A deleção genética foi observada em 16 dos $28(57,1 \%)$ pacientes com PAG que foram positivos para $A a$. Porém, nenhuma das amostras de indivíduos com saúde periodontal apresentaram a deleção $\left(\chi^{2}=19,15 ; \mathrm{p}<0,001\right)$. Correlações significantes entre a presença da deleção e os parâmetros clínicos $\mathrm{PBS}(\mathrm{r}=0,312, \mathrm{p}<0,05), \mathrm{NCI}(\mathrm{r}=0,406, \mathrm{p}<0,01)$, $\mathrm{PL}(\mathrm{r}=0,278, \mathrm{p}<0,05)$ e SAS ( $\mathrm{r}=0,409, \mathrm{p}<0,01)$ foram observadas. Uma alta prevalência de $A a$ foi observada em brasileiros com PAG e saúde periodontal, entretanto o genótipo altamente leucotóxico foi detectado somente em pacientes com doença agressiva.

Palavras-chave: periodontite agressiva generalizada, PCR, Actinobacillus actinomycetemcomitans, saliva, leukotoxina

\section{REFERENCES}

1. Al-Yahfoufi, Z.; Mombelli, A.; Wicki, A.; Lang, N.P. The occurrence of Actinobacillus actinomycetemcomitans, Porphyromonas gingivalis and Prevotella intermedia in an Arabic population with minimal periodontal disease. Microbial. Ecol. Heal. Dis., 7, 217224, 1994.

2. Armitage, G.C. Development of a classification system for periodontal diseases and conditions. Ann. Periodontol., 4, 1-6, 1999.

3. Ashimoto, A.; Chen, C.; Bakker, I.; Slots, J: Polymerase chain reaction of 8 putative periodontal pathogens in subgingival plaque of gingivitis and advanced periodontitis lesions. Oral Microbiol. Immunol., 11, 266-273, 1996.

4. Asikainen, S.; Alaluusua, S.; Saxen, L. Recovery of Actinobacillus actinomycetemcomitans from teeth, tongue, and saliva. $J$. Periodontol., 62, 203-206, 1991.

5. Ávila-Campos, M.J.; Velasquez-Melendez, G. Prevalence of putative periodontopathogens from periodontal patients and healthy subjects in São Paulo, Brazil. Rev. Inst. Med. Trop. SP, 44, 1-5, 2002.

6. Baehni, P.C.; Tsai, C.C.; McArthur, W.P.; Hammond, B.F.; Shenker, B.J.; Taichman, N.S. Leukotoxic activity in different strains of the bacterium Actinobacillus actinomycetemcomitans isolated from juvenile periodontitis in man. Arch. Oral Biol., 26, 671-676, 1981.

7. Beighton, D. The value of salivary bacterial counts in the prediction of caries activity. In: Risk markers for oral diseases, Johnson NW, Ed., Cambridge, 1991, pp.313-326.

8. Brazilian Institute of Geography and Statistics. Demographic Census 2003: Characteristics of the Population and Hoseholds (in Portuguese). Rio de Janeiro, Brazil, 2003.

9. Brogan, J.M.; Lally, E.T.; Poulsen, K.; Kilian, M.; Demuth, D.R. Regulation of Actinobacillus actinomycetemcomitans leukotoxin expression: analysis of the promoter regions of leukotoxic and minimally leukotoxic strains. Infect. Immun., 62, 501-508, 1994.

10. Bueno, L.C.; Mayer, M.P.; DiRienzo, J.M. Relationship between conversion of localized juvenile periodontitis-susceptible children from health to disease and Actinobacillus actinomycetemcomitans leukotoxin promoter structure. J. Periodontol., 70, 998-1007, 1998.

11. Colombo, A.P.; Teles, R.P.; Torres, M.C.; Souto, R.; Rosalem Junior, W.; Mendes, M.C.S.; Uzeda, M. Subgingival microbiota of Brazilian subjects with untreated chronic periodontitis. J. Periodontol., 73, 360-369, 2002.

12. Contreras, A.; Rusitanonta, T.; Chen, C.; Wagner, W.G.; Michalowicz, B.S.; Slots, J. Frequency of 530-bp deletion in Actinobacillus actinomycetemcomitans leukotoxin promoter region. Oral Microbiol. Immunol., 15, 338-340, 2000. 
13. Cortelli, S.C.; Jorge, A.O.C.; Cortelli, J.R.; Jordan, S.F.; Haraszthy, V.I. Detection of highly and minimally leukotoxic Actinobacillus actinomycetemcomitans strains in patients with periodontal disease. Pes. Odontol. Bras., 17, 183-188, 2003.

14. Cortelli, J.R.; Cortelli, S.C.; Jordan, S.F.; Haraszthy, V.I.; Zambon, J.J. Prevalence of periodontal pathogens in Brazilians with aggressive or chronic periodontitis. J. Clin. Periodontol., 32, 860-866, 2005.

15. Darout, I.A.; Albandar, J.M.; Skaug, N.; Ali, R.W. Salivary microbiota levels in relation to periodontal status, experience of caries and miswak use in Sudanese adults. J. Clin. Periodontol., 29, 411-420, 2002.

16. DiRienzo, J.M.; McKay, T.L. Identification and characterization of genetic cluster groups of Actinobacillus actinomycetemcomitans from the human oral cavity. J. Clin. Microbiol., 32, 75-81, 1994.

17. DiRienzo, J.M.; Slots, J.; Sixou, M.; Sol, M.A.; Harmon, R.; McKay, T.L. Specific genetic variants of Actinobacillus actinomycetemcomitans correlate with disease and health in a regional population of families with localized juvenile periodontitis. Infect. Immun., 62, 3058-3065, 1994.

18. Eisenmann, A.C.; Eisenmann, R.; Sousa, O.; Slots, J. Microbiological study of localized juvenile periodontitis in Panama. J. Periodontol., 54, 712-713, 1983

19. Felmlee, T.; Welch, R.A Alterations of amino acid repeats in the Escherichia coli hemolysin affect cytolytic activity and secretion. Proc. Natl. Acad. Sci. USA, 85, 5273-5279, 1988.

20. Gmur, R.; Guggenheim, B. Interdental supragingival plaque - a natural habitat of Actinobacillus actinomycetemcomitans, Bacteroides forsythus, Campylobacter rectus, and Prevotella nigrescens. J. Dent. Res., 73, 1421-1428, 1994.

21. Haffajee, A.D.; Socransky, S.S. Microbial etiological agents of destructive periodontal diseases. Periodontol. 2000, 5, 78-111, 1994.

22. Haraszthy, V.I.; Hariharan, G.; Tinoco, E.M.B.; Cortelli, J.R.; Lally, E.T.; Davis, E.; Zambon, J.J. Evidence for the role of highly leukotoxic Actinobacillus actinomycetemcomitans in a pathogenesis of localized juvenile and other forms of early-onset periodontitis. $J$. Periodontol., 71, 912-922, 2000.

23. Haubek, D.; Poulsen, K.; Asikainen, S.; Kilian, M. Evidence for absence in northern Europe of especially virulent clonal types of Actinobacillus actinomycetemcomitans. J. Clin. Microbiol., 33, 395401, 1995.

24. Haubek, D.; Poulsen, K.; Westergaard, J.; Dahlèn, G.; Kilian, M. Highly toxic clone of Actinobacillus actinomycetemcomitans in geographically widespread cases of juvenile periodontitis in adolescents of African origin. J. Clin. Microbiol., 34, 1576-1578, 1996.

25. Haubek, D.; Dirienzo, J.M.; Tinoco, E.M.B.; Westergaard, J.; Lopez, N.J.; Chung, C.P.; Poulsen, K.; Kilian, M. Racial tropism of a highly toxic clone of Actinobacillus actinomycetemcomitans associated with juvenile periodontitis. J. Clin. Microbiol., 35, 3037-3042, 1997.

26. Haubek, D.; Ennibi, O.K.; Poulsen, K.; Poulsen, S.; Benzarti, N.; Kilian, M. Early-onset periodontitis in Morocco is Associated with the highly leukotoxic clone of Actinobacillus actinomycetemcomitans. J. Dent. Res., 80, 1580-1583, 2001

27. Laine, M.L.; Farré, M.A.; Crusius, J.B.A.; van Winkelhoff, A.J.; Pena, A.S. The mouthwash: a non-invasive sampling method to study cytokine gene. J. Periodontol., 71, 1315-1318, 2000.

28. Lally, E.T.; Golub, E.E.; Kieba, I.R.; Taichman, N.S.; Rosenbloom, J.; Rosenbloom, J.C.; Gibson, C.W.; Demuth, D.R. Analysis of the Actinobacillus actinomycetemcomitans leukotoxin gene. Delineation of unique features and comparison to homologous toxins. J. Biol. Chem., 264, 15451-15456, 1989.

29. Lang, N.P.; Bartold, P.M.; Cullinam, M.; Jeffcoat, M.; Mombelli, A.; Murakami, S.; Page, R.; Papapanou, P.; Tonetti, M.; Van Dyke, T. International Classification Workshop. Consensus report: Aggressive periodontitis. Ann. Periodontol., 4, 53, 1999.
30. McNabb, H.; Mombelli, A.; Gmur, R.; Mathey-Dinc, S.; Lang, N.P. Periodontal pathogens in the shallow pockets of immigrants from developing countries. Oral Microbiol. Immunol., 7, 267-272, 1992.

31. Mombelli, A.; Gmur, R.; Lang, N.P.; Cobert, E.; Frey, J. Actinobacillus actinomycetemcomitans in Chinese adults. Serotype distribution and analysis of the leukotoxin gene promoter locus. $J$. Clin. Periodontol., 26, 505-510, 1999.

32. Riggio, M.P.; Macfarlane, T.W.; Mackenzie, D.; Lennon, A.; Smith, A.J.; Kinane, D. Comparison of polymerase chain reaction and culture methods for detection Actinobacillus actinomycetemcomitans and Porphyromonas gingivalis in subgingival plaque samples. $J$. Periodontal. Res., 31, 496-501, 1996.

33. Rosa, O.P.S.; Silva, S.M.B.; Costa, B.; Torres, S.A.; Passanezi, E. Periodontopathogens in the saliva and subgingival dental plaque of a group of mothers. Pes. Odontol. Bras., 16, 313-318, 2002.

34. Saarela, M.; Asikainen, S.; Jousimies-Somer, H.; Asikainen, T.; von Troil-Lindén, B.; Alaluusua, S. Hybridization patterns of Actinobacillus actinomycetemcomitans serotypes a-e detected with an rRNA gene probe. Oral Microbiol. Immunol., 8, 111-115, 1993.

35. Sakamoto, M.; Takeuchi, Y.; Umeda, M.; Ishikawa, I.; Benno, Y.; Nakase, T. Detection of Treponema socranskii associated with human periodontitis by PCR. Oral Microbiol. Immunol., 43, 485490, 1999.

36. Savitt, E.D.; Strzempko, M.N.; Vaccaro, K.K.; Pero, W.J.; French, C.K. Comparison of cultural methods and DNA probe analyses for the detection of Actinobacillus actinomycetemcomitans, Bacteroides gingivalis and Bacteroides intermedius in plaque samples. J. Periodontol., 59, 431-438, 1988.

37. Slots, J.; Reynolds, H.S.; Genco, R.J. Actinobacillus actinomycetemcomitans in human periodontal disease: a crosssectional microbiological investigation. Infect. Immun., 29, 10131020,1980

38. Slots, J.; Genco, R.J. Black - pigmented Bacteroides species, Capnocytophaga species, and Actinobacillus actinomycetemcomitans in human periodontal disease: virulence factors in colonization, survival, and tissue destruction. J. Dent. Res., 63, 412-421, 1984.

39. Slots, J.; Ting, M. Actinobacillus actinomycetemcomitans and Porphyromonas gingivalis in human periodontal disease: occurrence and treatment. Periodontol. 2000, 20, 82-121, 1999.

40. Socransky, S.S.; Haffajee, A.D. The bacterial etiology of destructive periodontal disease: current concepts. J. Periodontol., 63, 322-331, 1992.

41. Tan, K.S.; Woo, C.H.; Ong, G.; Song, K.P. Prevalence of Actinobacillus actinomycetemcomitans in an ethnic adult Chinese population. $J$. Clin. Periodontol., 28, 886-890, 2001.

42. Testa, M.; Ruiz de Valladares, R.; Benito de Cardenas, I.L. Correlation between bacterial counts in saliva and subgingival plaque. Acta Odontol. Lat. Am., 12, 63-74, 1999.

43. Tinoco, E.M.B.; Stevens, R.; Haubek, D.; Lai, C.H.; Balachandran, S.; Preus, H. Relationship of serotype, leukotoxin gene type and lysogeny in Actinobacillus actinomycetemcomitans to periodontal disease status. Eur. J. Oral Sci., 195, 310-317, 1997.

44. Tinoco, E.M.B.; Beldi, M.I.; Loureiro, C.A.; Lana, M.; Campedelli, F.; Tinoco, N.M.; Gjermo, P.; Preus, H.R. Localized juvenile periodontitis and Actinobacillus actinomycetemcomitans in a Brazilian population. Eur. J. Oral Sci., 105, 9-14, 1997.

45. Tinoco, E.M.B.; Sivakumar, M.; Preus, H.R. The distribution and transmission of Actinobacillus actinomycetemcomitans in families with localized juvenile periodontitis. J. Clin. Periodontol., 25, 99$105,1998$.

46. Tonjum, T.; Haas, R. Identification of Actinobacillus actinomycetemcomitans by leukotoxin gene-specific hybridization and polymerase chain reaction assays. J. Clin. Microbiol., 31, 1856$1856,1993$. 
47. Umeda, M.; Contreras, A.; Chen, C.; Bakker, I.; Slots, J. The utility of whole saliva to detect oral presence of periodontopathic bactéria. J. Periodontol., 69, 828-833, 1998.

48. Van der Velden, U.; van Winkelhoff, A.J.; Abbas, F.; de Graaff, J. The habitat of periodontopathic microorganisms. J. Clin. Periodontol., 13, 243-248, 1986.

49. Van Winkelhoff, A.J.; Rodenburg, J.P.; Goene, R.J.; Abbas, F.; Winkel, E.G.; Gras, J. Metronidazole plus amoxicillin in the treatment of Actinobacillus actinomycetemcomitans associated periodontitis. J. Clin. Periodontol., 16, 128-131, 1989.

50. von Troil-Linden, B.; Torkko, H.; Alauusua, S.; Jousimies-Somer, H.; Asikainen, S. Salivary levels of suspected periodontal pathogens in relation to periodontal status and treatment. J. Dent. Res., 74, 1789-1793, 1995.

51. Willis, S.G.; Smith, K.S.; Dunn, V.L.; Gapter, L.A.; Riviere, K.H.; Riviere, G.R. Identification of seven Treponema species in health- and disease-associated dental plaque by nested PCR. J. Clin. Microbiol., 37, 867-869, 1999.

52. Zambon, J.J.; Christersson, L.A.; Slots, J. Actinobacillus actinomycetemcomitans in human periodontal disease. Prevalence in patient groups and distribution of biotypes and serotypes within families. J. Periodontol., 54, 707-711, 1983.

53. Zambon, J.J. Actinobacillus actinomycetemcomitans in human periodontal disease: J. Clin. Periodontol., 12, 1-20, 1985.

54. Zambon, J.J.; Umemoto, T.; De Nardin, E.; Nakazawa, F.; Christersson, L.A.; Genco, R.J. Actinobacillus actinomycetemcomitans in the pathogenesis of human periodontal disease. Adv. Dent. Res., 2, 269$274,1988$.

55. Zambon, J.J.; Haraszthy, V.I.; Hariharan, G.; Lally, E.T.; Demuth, D.R. The microbiology of early-onset periodontitis: Association of highly toxic Actinobacillus actinomycetemcomitans strains with localized juvenile periodontitis. J. Periodontol., 67, 282-290, 1996. 